\title{
Energy-Saving Potential of Daylighting in the Atria of Colleges in Najran University, Saudi Arabia
}

\author{
Abdultawab Mohammed Qahtan \\ Department of Architectural Engineering, College of Engineering, Najran University, Najran, Saudi Arabia \\ Email: tawab444@gmail.com \\ Diaeldin A Ebrahim and Hussein M. Ahmed \\ Department of Electrical Engineering, Faculty of Engineering, Alzaiem Alazhari University, Khartoum, Sudan
}

\begin{abstract}
Daylighting is recognised as an effective strategy for enhancing visual comfort and reducing energy used for electric lighting. Najran University, Saudi Arabia, has 15 colleges for males and 10 colleges for females. Each college has several atria and courtyards for introducing daylighting into the hearts of college buildings. However, the electrical lights used in the colleges atria and linked corridors keep on all the daytime. This study is an attempt to investigate the daylight illuminance level and energy-saving potential on the atria and linked corridors when it incorporates a timescheduling lighting control system. The field measurements were performed in the College of Applied Medical Sciences. The results indicate that daylight illuminance in the atrium spaces are abundant with an average illumination level on the atrium floor varying from 300 lux to 3600 lux, depending on the time of the day. In the clear sky climate of Najran city throughout the year, the time-scheduling control system is effective and found to contribute to approximately $43855.2 \mathrm{kWh}$ of annual energy savings in electrical-lighting consumption in the present case study scenario. The total annual energy savings from all 25 colleges at Najran University is 1096380 $\mathrm{kWh} /$ year, which results in a cost saving of approximately 93,512.86 USD. There would be additional substantial savings from other atria and courtyards in all of the college buildings throughout the campus.
\end{abstract}

(C) 2020 Penerbit UTM Press. All rights reserved

\author{
Article History \\ Received : 24 May 2019 \\ Received in revised form : 26 August 2019 \\ Accepted: 15 December 2019 \\ Published Online: 31 December 2019
}

Keywords:

Building atrium, Case study, Daylight illuminance, Clear sky, Energy saving, Lighting control.

Corresponding Author's Contact:

DOI: $10.11113 /$ ijbes.v7.n1.421

\section{Introduction}

Buildings with daylight help keep users physically and emotionally healthy (Aries, Aarts, \& van Hoof, 2015). Using daylight as the primary light source of indoor structures is widely recognised as an important strategy to reduce building energy consumption and enhance indoor environment quality (Hua, Oswald, \& Yang, 2011). In atrium buildings, there is adequate daylight contribution to the ground floor of the atrium and its adjacent spaces, thus eliminating a large portion of the need for electrical lighting.
However, careful building design with daylighting can not only be an effective means in the reduction of energy consumption, but also, it is regarded as a beneficial design concept for numerous other reasons, such as outdoor connections, human health, comfort and satisfaction, particularly when carefully designing the building to be integrated with electrical lighting (Sabry, 2006). However, providing the required lighting levels for various activities in a building from daylight alone is becoming increasingly difficult, due to the limitation of building form and the increased building density. The design of the atrium should 
ensure effective daylighting without increasing the heat gain into the building interior (Abdou, 1997) (Costanzo, Evola, \& Marletta, 2017), particularly in a hot and dry climate.

Colleges in Najran University that located in a hot dry region of Saudi Arabia, incorporate atria for introducing daylighting to the heart of the colleges building and to the corridors surrounding the atria. Each atrium and linked corridors have different types of lights that keep on all the daytime and are switched off at midnight by Building management system (BMS). Recently, "The General Administration of Projects and Technical Affairs" of Najran University started installing On-Off light switches in the atria to control the lamps. However, the lamps are not appropriately controlled and stay lit during the day causing energy waste. To address this problem, the study aims to investigate the indoor illuminance from daylighting on a selected atrium and linked corridors (College of Applied Medical Sciences). It is also a numerical attempt to estimate the energy-saving potential when the atrium and linked corridors incorporate a time-scheduling lighting control system.

\subsection{Daylight in Atrium Buildings}

Daylighting can be defined as the introduction of natural light to the interior. An atrium is typically a large and multi-storeyed, glass-roofed space to introduce daylight to the interiors of large buildings where sidelight alone cannot penetrate the spaces (Mark \& G. Z., 2014). However, in a hot and dry climate, the atrium or enclosed courtyard brings natural light indoors and keeps the indoors relatively cool as it is self-shading most of the day and protected from hot winds (Lechner, 2015). Moreover, the atrium increases the total area exposed to daylight by providing a large opening in the building core, and, accordingly, energy savings can be achieved (Stanley K.H. Chow, 2013). The amount of this daylighting available on the floor of the atrium depends on several factors, namely, the translucency of the atrium roof, the reflectance of the atrium walls and the geometry of the space (depth versus width) (Lechner, 2015). The recommended illumination level on the floor of the atrium was recorded in some studies as 100 lux and in IES standard as a maintained horizontal illumination of 200 lux (Hourani \& Hammad, 2012).

\subsection{Building Energy Consumption in Saudi Arabia}

According to the Saudi Energy Efficiency Centre (SEEC, 2018), buildings are the main contributors to energy use and account for more than $50 \%$ of the total energy consumption in Saudi Arabia. According to the 2011 annual report by the Electricity \& Cogeneration Regulatory Authority, consumption in Buildings Sector was approximately $80 \%$ of the total electricity generated in
Saudi Arabia. Furthermore, per capita electricity consumption is also increasing rapidly in the kingdom due to numerous factors, such as population growth and increased use of energy-intensive appliances. Hence, the electricity demand in Saudi Arabia is expected to double by 2025 (Obaid \& Mufti, 2008). Several studies have shown that daylight, if used as a main source of illumination inside buildings, can significantly reduce lighting and cooling loads and eventually result in savings in energy consumption (Alshaibani, 2001) (PE., 1991) (Chow, Li, Lee, \& Lam, 2013) (Mahdavi, Rao, \& Inangda, 2013). This electricallighting consumption saving can reach up to $75 \%-80 \%$ if the buildings use advanced daylighting technologies and have improved integration of daylighting systems (Veronica G., 2006) (Atif \& Galasiu, 2003) (USGBC, 2018).

Energy-efficient lighting also includes considerations of the control of electrical lighting besides the use of daylight. Nowadays, the most common form of control is the standard wall switch that has been replaced, in many applications, with automatic control, such as occupancy sensing, daylight harvesting control or time scheduling. The use of lighting control systems, based on presence detection and the integration of electrical light with daylight, can lead to substantial energy savings. Previous studies reported that lighting control can lead to energy savings varying from $10 \%$ with a simple time scheduling to $60 \%$ with a total integrated solution (Halonen, Bhusal, \& Y, 2010). These lighting controls will be used for maintaining the illuminance level of 100-200 lux on the floors of the corridors as well as atrium.

\subsection{Availability of Daylight From Najran Sky}

Najran is a city in southwestern Saudi Arabia, with a latitude of $17^{\circ} 29^{\prime} 30^{\prime \prime} \mathrm{N}$ and a longitude of $44^{\circ} 7^{\prime} 56^{\prime \prime}$ E. Najran City has a desert climate where the average monthly temperature varies between $17{ }^{\circ} \mathrm{C}$ in winter and $45{ }^{\circ} \mathrm{C}$ in summer. Saudi Arabia is the second sunniest place on Earth (Mansour, Sawalha, \& Salem, 2013), and Najran is among the cities with the highest daily solar radiation in Saudi Arabia of more than $6.9 \mathrm{kwh} / \mathrm{m} 2 /$ day (Zell, Gasim, Wilcox, Katamoura, \& Stoffel, 2015). Table 1 shows that Najran City receives more than 3600 sunlight hours per year with an average of 10 sunny hours per day over the course of the year. The monthly sunshine hours vary on average between $357 \mathrm{~h}$ on April to August and $260 \mathrm{~h}$ on the remaining months of the year. Moreover, Table 1 presents the cloud cover of Najran City with an average peak below 20\%. The CIE standard defines the Clearsky as a sky with less than $30 \%$ of clouds covering, while a sky with more than 70\% cloud cover is a Cloud-sky (IESNA, 2000). Thus, Najran city has a clear sky throughout the year. 
Table 1 Average monthly sunlight hours, Global Horizontal Irradiance and cloud cover of Najran City. Authors based NU weather station and on (WWO, 2018).

\begin{tabular}{|c|c|c|c|c|c|c|c|c|c|c|c|c|}
\hline Month & Jan & Feb. & Mar. & April & May & June & July & Aug. & Sep. & Oct & Nov. & Dec. \\
\hline Sun Hours & 230 & 260 & 315 & 372 & 386 & 375 & 374 & 372 & 346 & 301 & 225 & 231 \\
\hline $\begin{array}{l}\text { Global Horizontal } \\
\text { Irradiance } W h / m 2\end{array}$ & 229 & 268 & 285 & 294 & 317 & 322 & 295 & 300 & 294 & 285 & 246 & 222 \\
\hline Cloud cover \% & 1 & 16 & 10 & 5 & 3 & 2 & 17 & 15 & 1 & 0 & 2 & 1 \\
\hline CIE Overcast range $\%$ & \multicolumn{12}{|c|}{$\geq 8$} \\
\hline
\end{tabular}

Daylight in a clear and sunny sky condition is a challenge where direct sunlight on a clear day can generate illuminance levels of up to 100000 lux at midday (Frank, Doug, Jeff, \& Josh, 2014). Daylighting in such climate is associated with negative factors, such as glare and increased cooling loads. The challenge is to control daylight in a way that light is utilised without glare and the heat is kept out (YILMAZ, 2016). Moreover, the sky condition of Najran City is clear and sunny throughout the year, which renders investigating the daylight factor associated with the worst sky condition of the overcast sky difficult. Thus, the daylight illuminance under the clear sky of Najran city will be measured and discussed in this study.

\section{Methodology}

This study adopts a case study method to investigate the daylight illuminance level in atria and linked corridors in the College of Applied Medical Sciences at Najran University, under the hot arid climate of Najran City. A daylight illuminance of a selected atrium was measured on different days of the year. Lighting fittings were monitored and calculation was conducted to report the energy saving from a daylight harvesting.

\subsection{Description of the Case Study}

Buildings of colleges at Najran University were designed with a skylight and enclosed atria to harvest daylight, enhance visual comfort and to reduce the electricity consumption by electrical lightings. The atrium of the College of Applied Medical Sciences at Najran University in Najran City (with a latitude of $17^{\circ} 29^{\prime} 30^{\prime \prime}$ $\mathrm{N}$ and a longitude of $44^{\circ} 7^{\prime} 56^{\prime \prime} \mathrm{E}$ ) was investigated. The atrium is an enclosed type that has a square shape with a daylight source and view from the triple glazing skylight and an entrance at the ground floor. The lower part of the atrium from the G/F consists of corridors and the entrance to auditoriums. The upper part, between the $1 / \mathrm{F}$ and $2 / \mathrm{F}$, contains corridors, lecture halls and offices.

The College of Applied Medical Sciences (Figure 1) is a threestorey building with exterior dimensions of $202 \mathrm{~m} \mathrm{x} 132 \mathrm{~m}$. The building has two atria, namely, the first at the entrance for the administrators and the second at the entrance for the students. The investigated atrium is the entrance of the students with a space that is primarily used for circulation to different locations within the building. The monitored atrium and corridors are highlighted by the shaded regions. Corridors surrounding the atrium are connected to the auditoriums, lectures halls and lecturers' offices. The atrium has a maximum height of $20 \mathrm{~m}$, extending from the ground floor to the roof level of the atrium. The ground floor area of the atrium is $400 \mathrm{~m} 2$ and the total floor area of the surrounding walkways is $200 \mathrm{~m} 2$. Figure 2 show the interior views of the investigated atrium. The roof is green tinted and triple glazed with an area of approximately $100 \%$ of the total projected atrium roof area. The three layers of glass in triple glazing are $6 \mathrm{~mm}$ green-tinted glass, and the remaining two are clear glass, from outside to inside. The exterior glass panel (green-tinted) of a triple-glazing roof has a manufacturer-stated visible transmittance of $6 \%$, and its measured average net visible transmittance is approximately $3 \%$ under clear sky. Daylight also enters the atrium space from a northeast glazing wall of the ground floor, which is the entrance of the students.

The atrium space has a total of 16 lamps, $400 \mathrm{~W}$ each, halogen lamp hanging fixtures that are uniformly distributed on the atrium spaceframe to supplement lighting to the atrium floor. The lighting system also includes a total of 56 lamps, $52 \mathrm{~W}$ for each, recessed compact fluorescent fixtures uniformly distributed along the walkways surrounding the atrium space at all levels.

\section{$2.2 \quad$ Field Measurements}

The daylighting of the atrium space was monitored at different times of the year, on 18 January 2018 (different times of the day) to represent wintertime with a minimum global horizontal irradiance of $229 \mathrm{Wh} / \mathrm{m} 2$, and 25 June 2018 at midday to represent summer and days with a highest value of global horizontal irradiance of $322 \mathrm{Wh} / \mathrm{m} 2$. An initial measurement was conducted on 21 September 2017 where daytime and night-time are of approximately equal as well as the academic year starts. In hot sunny regions, such as Najran city, measuring daylight illuminance on a sunny day is sufficient because the sky condition throughout the year is almost sunny and clear sky.

As the designer considers the availability of daylighting firstly for the lowest floor (Grondzik \& Kwok, 2015), the horizontal indoor illuminance measurements were collected on the atrium floor, under clear conditions to address the daylighting contribution to the atrium space. A total of 70 test points at the atrium floor area with grid space of $2.0 \times 2.5 \mathrm{~m}$ were monitored on the horizontal work-plane, at floor height of $0.2 \mathrm{~m}$. The measurements were taken over an hour duration, starting at 10:00 a.m. and ending at 11:00 a.m. Moreover, 20 test points were monitored in the corridors linked to the atrium with no electrical lighting as well. 
Measurements were also collected at night-time $(9: 00 \mathrm{pm}$.$) for$ confirming the electrical lighting distribution at night. The outer test point was performed outdoor, away from the atrium. The collected data samples have been recorded using an AMPROBE LM-100 light meter with a basic accuracy of $\pm 5 \%$.

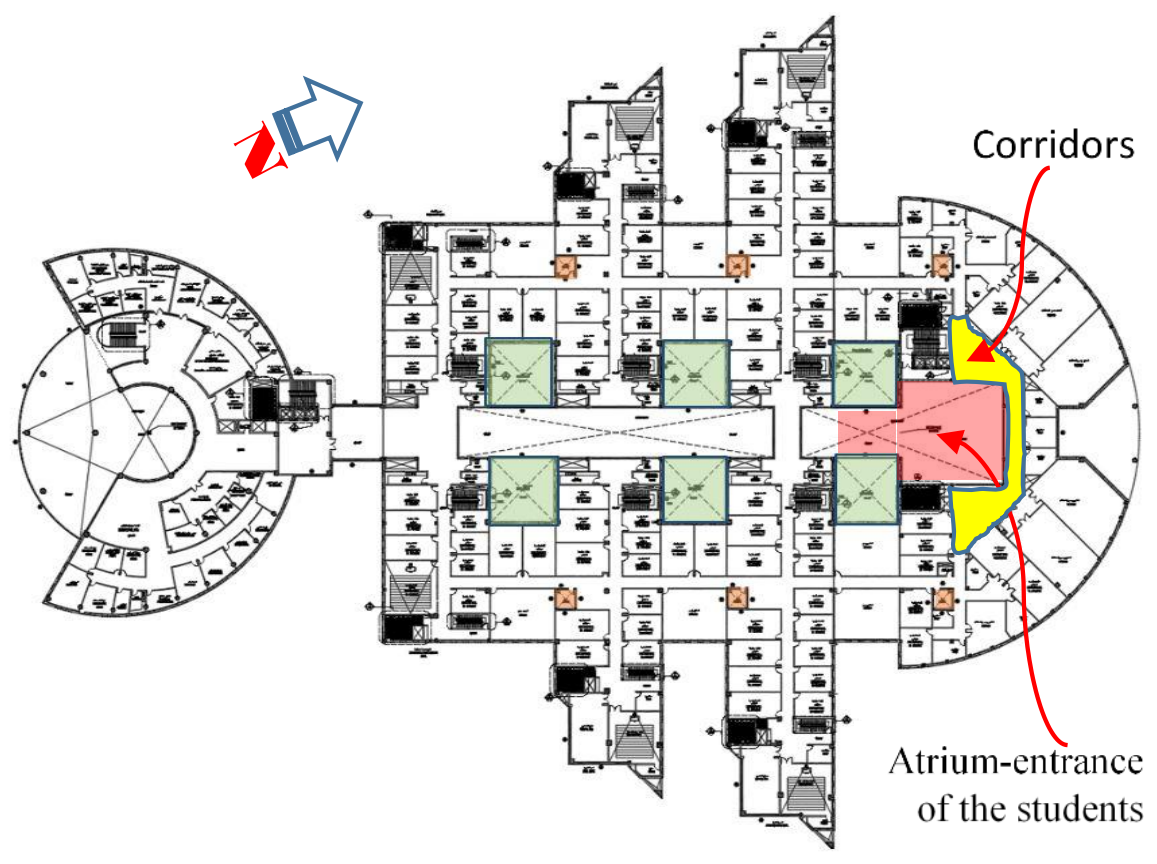

Figure 1. Plan of the College of Applied Medical Sciences, shows the investigated atrium.
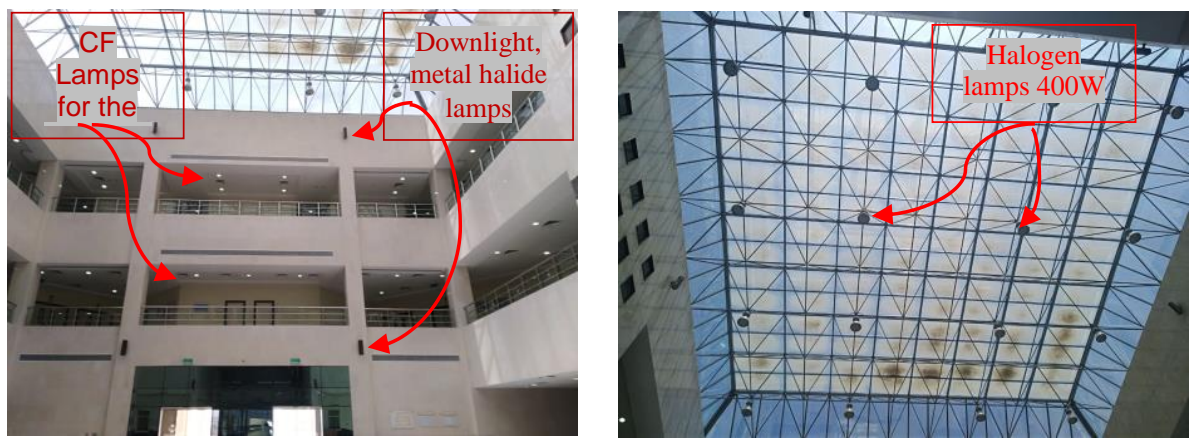

Figure 2. Interior views of the investigated atrium (Authors).

\section{Results and discussion}

\subsection{Daylight Contribution To The Atrium Spaces}

As Najran City has a clear sky condition over the year, daylight is considered a sustainable source of light. The supply of daylight is typically during the day hours with peak occupancy and electrical energy loads. Usually, daylight can sufficiently meet the demand for lighting the building during working hours. According to the American IES Standards, atrium and circulation space have work-plane illumination requirements ranging from 50 lux to 200 lux (Kim \& Kim, 2010).

Figures 3 and 4, show the daylight contribution to the atrium and its distribution on the atrium floor that has been measured on 18 January 2018 at 10am. The measured points, (Fig.3), have been recorded on the horizontal work-plane, at floor height of $0.2 \mathrm{~m}$ of the investigated atrium with grid space of 2.0 $\times 2.5 \mathrm{~m}$. The plotted contour lines (Fig.4), shows that the daylight illuminance on the atrium floor were very high and vary from one point to the other (600lux to 2500lux). This variation is due to the exposure of some measured points to the direct solar radiation, whereas the others were shielded by dust collected on the glazed roof of the atrium.

Figure 5 shows the average daylight illuminance in the atrium and surrounding corridors spaces at different times of the day. The measurements took place on18 January 2018. Several 
points on the atrium floor were measured at 7 a.m., 10 a.m., 2 p.m. and 5 p.m. The Figure shows that the average indoor daylight illuminance on the atrium floor was 1078 lux, 1290 lux, 3600 lux and 281 lux respectively. The outdoor illuminance was 8980 lux, 80000 lux, 110000 lux and 2594 lux respectively as well. These daylight illuminance values throughout the daytime remained sufficient for atrium activities compared to the recommended illuminance of $(100-200)$ lux. However, the high lux value at 2 p.m. is due to direct illumination from the sun where the atrium glazed-roof exposed to high value of outdoor illuminance of 110000 lux. Figure 5, also, shows the daylight illuminance on the floor of the measured corridors of the first and second levels. The daylight illuminance level appeared almost the same. Table 2 summarizes the daylight illuminance at the atrium and linked-corridors that were found exceeding the requirements of atrium and circulation spaces by $10-20$ times particularly at 10a.m. and 2p.m. Table 2, also, illustrates Measurements that were done during the night time for confirming the electrical lighting distribution in the investigated spaces at 9:00 p.m. The illuminance level varied between 140 lux on the atrium floor and 100 lux on the floors of the surrounding corridors, which is an acceptable light level for the circulation areas.

Moreover, the measurement was conducted at the atrium floor during summer time; on 25 July 2018 at midday, the peak illuminance rate was found to be almost 30000 lux (when outdoor was 110 Klux), which is a high-level illumination. In accordance with the previous studies based on the occupant behaviour under daylight conditions (Mardaljevic \& Nabil, 2006), the range of 100-2000 lux is the limit of useful daylight illuminance. However, the daylight illuminance values at the studied atrium spaces were found exceeding the useful range with a lux rate greater than 2000 lux in most of the atrium floor area.

In this context, it is important to report that in the hot-arid climate of “Rub' al Khali Desert” of Saudi Arabia, such as Najran City, the exposure of the atrium glass roof to direct solar radiation is creating the risk of glare as well as overheating. Thus, a dynamic solar shading system on the atrium-glazing roof is advisable to provide glare and heat protection. This issue, however, is beyond the scope of this study and could be covered by the future studies.

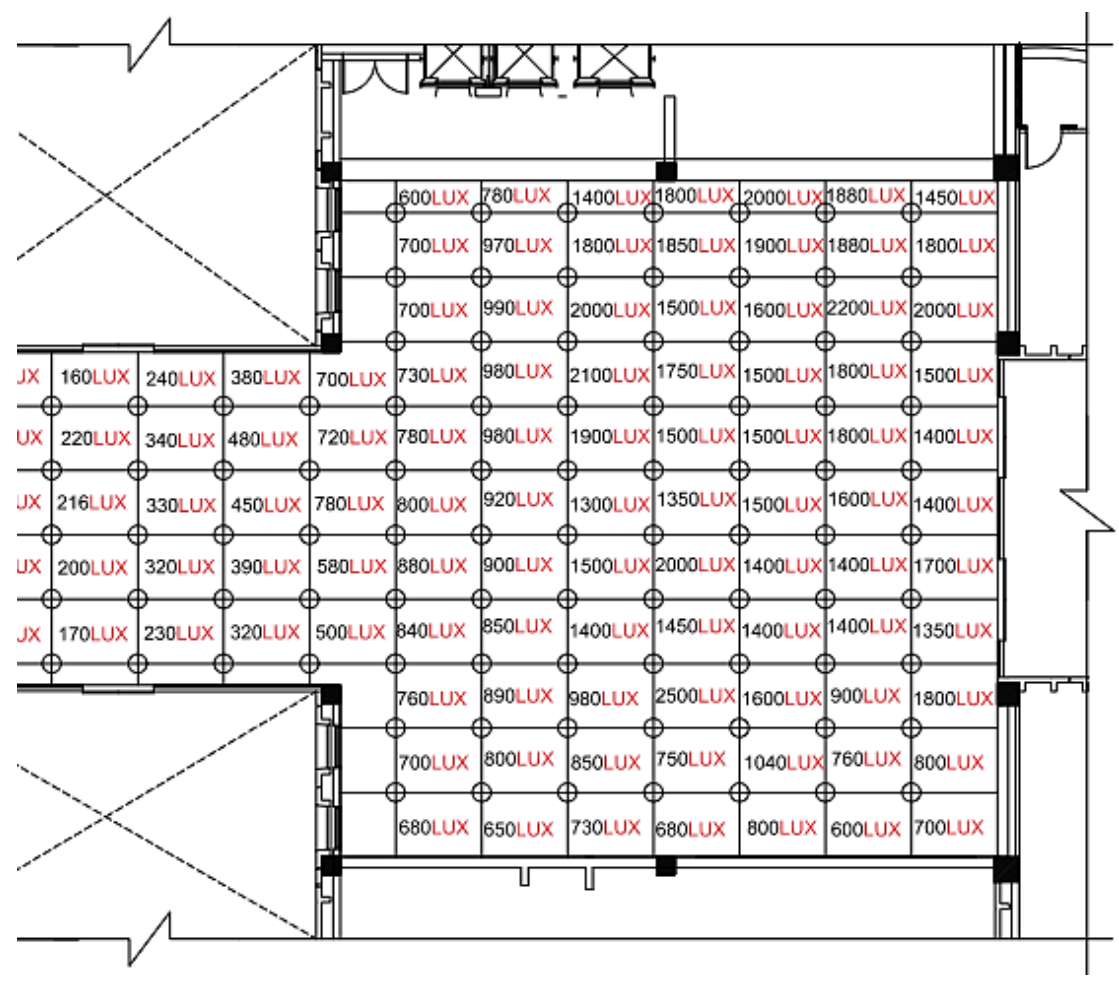

Figure 3. Illuminance level on the test points at the atrium floor area, at 10:00 a.m. 


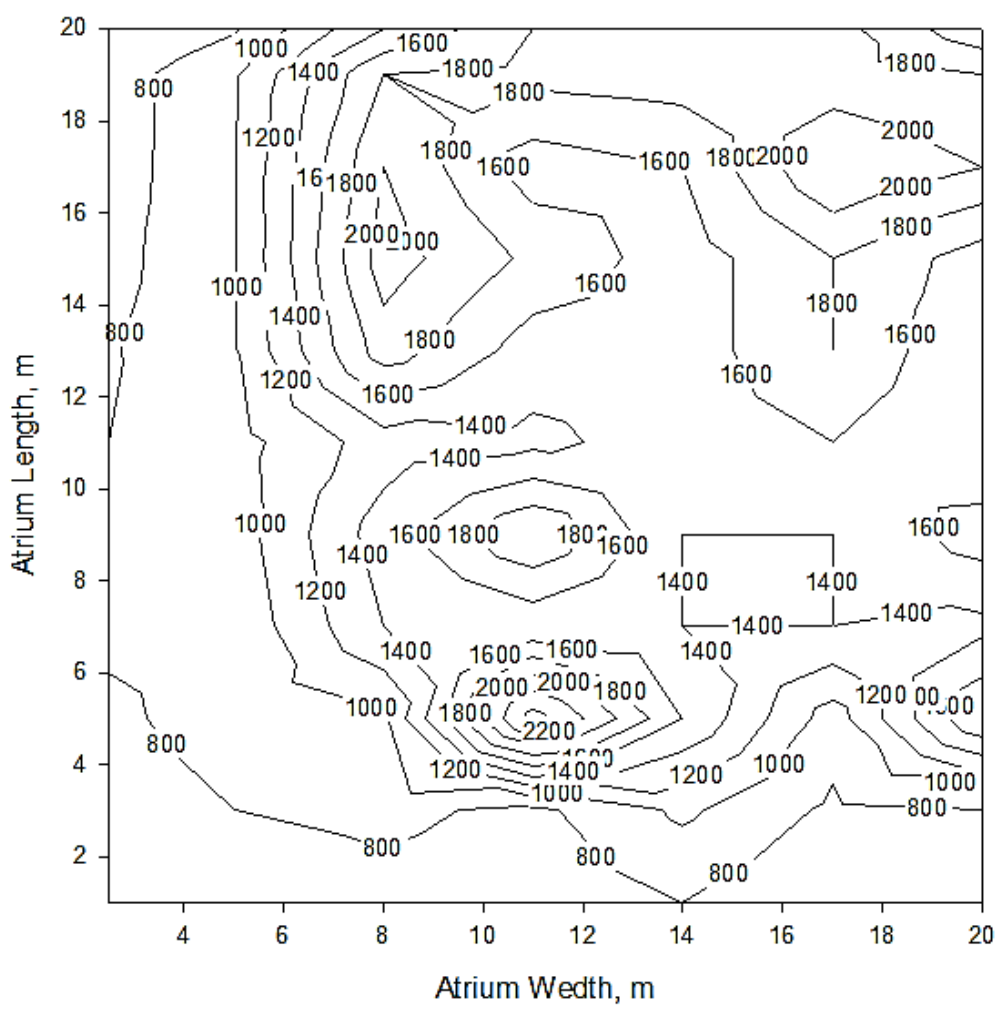

Figure 4. The contour lines of daylight illuminance level on the investigated atrium floor.

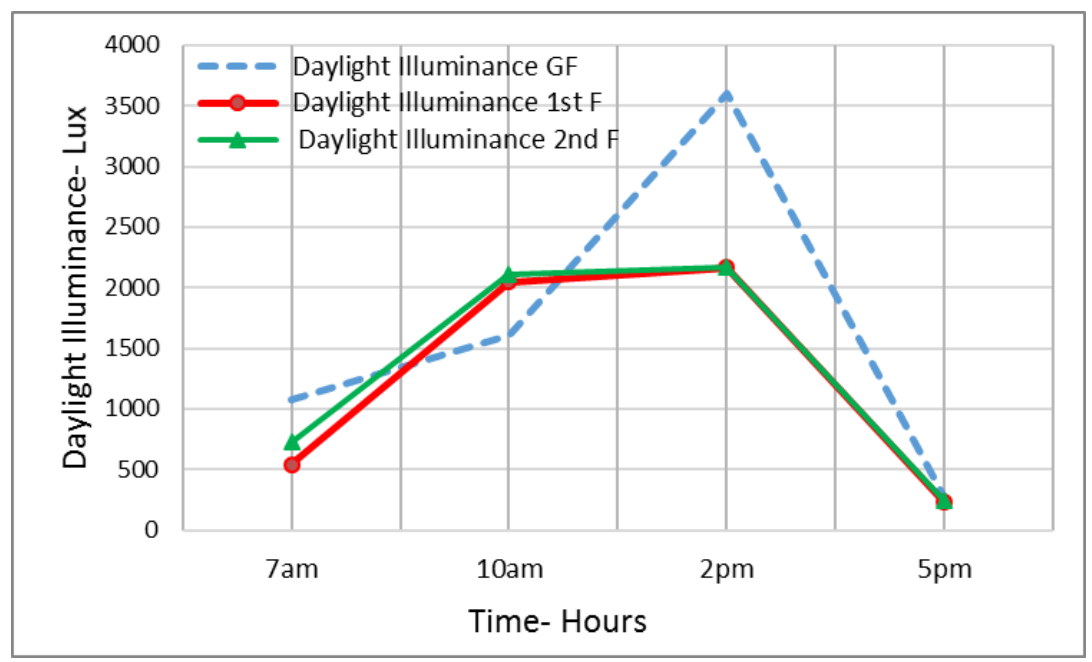

Figure 5. Daylight Illuminance distribution on the atrium floor and linked corridors at different times of the day.

Table 2. Average daylight Illuminance at different time of the day, 18 January 2018.

\begin{tabular}{ccccc}
\hline Time & $\begin{array}{c}\text { Daylight } \\
\text { Illuminance GF, } \\
\text { Lux }\end{array}$ & $\begin{array}{c}\text { Daylight Illuminance } \\
\text { 1st F, Lux }\end{array}$ & $\begin{array}{c}\text { Daylight Illuminance } \\
\text { 2nd F, Lux }\end{array}$ & $\begin{array}{c}\text { Outdoor } \\
\text { Lux }\end{array}$ \\
\hline \hline 7am & 1078 & 543 & 731 & 8980 \\
\hline $\mathbf{1 0 a m}$ & 1610 & 2050 & 2110 & 80000 On 18 January 2018: \\
\hline $\mathbf{2 p m}$ & 3600 & 2166 & 2164 & 110 Sun Rise Time (6:37) \\
\hline $\mathbf{5 p m}$ & 281 & 236 & 245 & 2 Sun Set Time (5:50) \\
\hline
\end{tabular}




\subsection{Lighting Energy Savings Estimation}

Interior daylight by the use of daylighting reduces the level of electrical lighting and it offers a substantial energy savings. The key to designing an integrated lighting system is the electrical lighting control system. An automatic control system of time scheduling is a suitable system in such a sky condition of Najran City, for switching off selected groups of luminaires from 6:00 a.m. to 6:00 p.m.

However, Electricity consumption for the Halogen, Metalhalide and CF light fittings in the atrium and linked-corridors located at first and second floor under the automatic Time schedule /on-off controls were calculated and summarised in Table 3. The table summarises the yearly energy savings in the atrium and linked-corridors at the College of Applied Medical Sciences, Najran University.

As energy consumption by the electrical lighting equals:

$$
\mathrm{E}=\mathrm{P} \times \mathrm{t}
$$

Where $E$ represents total energy consumption of the lamps, $P$ lamps output power (W) and $t$ running time (h), (A. C. Menezes, 2014).

Thus, the energy saving from the daylight at the atrium during daytime (12) hours for 30 days for 12 months is equal to
$43855.2 \mathrm{kWh} /$ year; this value is equivalent to 43.855 Mwh per year.

\subsection{Energy performance of Atria Throughout Najran University}

As mentioned earlier, the two campuses of Najran University have 25 colleges for males and females. Each college has two atria introducing daylighting to the heart of the college building and to the corridors surrounding the atria. The annual energy savings from one atrium of these almost identical colleges in Najran University is $43,855.2 \mathrm{kWh} /$ year. This value of energy saving is encouraging if applied to all of the 25 colleges of the university. However, by considering only the atrium of the entrance of the students, the total annual energy saving from all colleges in Najran University is $(43,855.2 \mathrm{kWh} /$ year $\times 25=$ 1,096,380 $\mathrm{kWh} /$ year). Therefore, Table 4 summarises the energy and cost saving from the investigated atrium and 25 similar atria throughout Najran University. The time-schedule lighting control system has been proved in this study to be retrofitted in the BMS of Najran University to switch off lightings in the atria and linked-corridors spaces from 6am to $6 \mathrm{pm}$ for energy and cost saving.

Table 3. Energy saving records at the entrance and corridors at Najran University.

\begin{tabular}{|c|c|c|c|c|c|c|c|c|}
\hline Space & $\begin{array}{l}\text { Daylight } \\
\text { system }\end{array}$ & $\begin{array}{l}\text { Type of } \\
\text { lamp }\end{array}$ & $\begin{array}{l}\text { No. of } \\
\text { lamps }\end{array}$ & Wattage & $\begin{array}{c}\text { Total } \\
\text { KW }\end{array}$ & $\begin{array}{c}\text { Proposed } \\
\text { Control } \\
\text { system }\end{array}$ & $\begin{array}{c}\text { Energy } \\
\text { saving/day } \\
\text { (kWh/day) }\end{array}$ & $\begin{array}{c}\text { Annual } \\
\text { energy } \\
\text { saving } \\
(\mathrm{kWh} / \mathrm{y}) \\
\end{array}$ \\
\hline \multirow{2}{*}{$\begin{array}{l}\text { Atrium } \\
\text { space }\end{array}$} & \multirow{2}{*}{$\begin{array}{l}\text { Skylight atrium } \\
\text { glazed roof }\end{array}$} & Halogen & 16 & $400 \mathrm{~W}$ & 6.400 & $\begin{array}{c}\text { Time schedule } \\
\text { off: 6:00 a.m.- } \\
\text { 6:00 p.m. }\end{array}$ & 76.8 & 27648 \\
\hline & & $\begin{array}{l}\text { Metal } \\
\text { halide }\end{array}$ & 12 & $70 \mathrm{~W}$ & 0.840 & $\begin{array}{c}\text { Time schedule } \\
\text { off: 6:00 a.m.- } \\
\text { 6:00 p.m. }\end{array}$ & 10.08 & 3628.8 \\
\hline $\begin{array}{c}\text { Corridors } \\
1 \text { st F }\end{array}$ & $\begin{array}{l}\text { Skylight atrium } \\
\text { glazed roof }\end{array}$ & CF lamp & 28 & $52 \mathrm{w}$ & 1.456 & $\begin{array}{c}\text { Time schedule } \\
\text { off: 6:00 a.m.- } \\
\text { 6:00 p.m. }\end{array}$ & 17.47 & 6289.2 \\
\hline $\begin{array}{l}\text { Corridors } \\
\text { 2nd F }\end{array}$ & $\begin{array}{l}\text { Skylight atrium } \\
\text { glazed roof }\end{array}$ & CF lamp & 28 & $52 \mathrm{w}$ & 1.456 & $\begin{array}{c}\text { Time schedule } \\
\text { off: 6:00 a.m.- } \\
\text { 6:00 p.m. }\end{array}$ & 17.47 & 6289.2 \\
\hline \multicolumn{8}{|c|}{ Total energy saving per year (KWh/ Y) } & $\begin{array}{l}43855.2 \\
\mathrm{kWh} / \mathrm{Y}\end{array}$ \\
\hline \multicolumn{8}{|c|}{ Total energy saving per year (MWh/ y) } & $43.855 \mathrm{MW} / \mathrm{Y}$ \\
\hline
\end{tabular}

Table 4. The effects of the Proposed Control system on cost savings.

\begin{tabular}{ccccc}
\hline Area estimation & $\begin{array}{c}\text { Energy saving } \\
\text { (kWh/year) }\end{array}$ & $\begin{array}{c}\text { Electricity Tariffs for } \\
\text { Governmental } \\
\text { (Riyals / kwh) }\end{array}$ & $\begin{array}{c}\text { Cost saving } \\
\text { SR }\end{array}$ & $\begin{array}{c}\text { Cost saving } \\
\text { USD }\end{array}$ \\
\hline \hline Investigated atrium & 43855.2 & 0.32 & 14033.664 & $3,740.51$ \\
\hline $\begin{array}{c}\text { Throughout Najran } \\
\text { University }\end{array}$ & $\begin{array}{c}43855.2 \times 25 \text { colleges }= \\
109,6380\end{array}$ & & $350,841.6$ & $93,512.86$ \\
\hline
\end{tabular}




\section{Conclusions and Recommendations}

This research combines daylight and energy assessment for the atrium and surrounding corridors in education buildings in a hot arid climate. Najran City has a clear sky throughout the year with abundant daylight to meet the demand for lighting a building during working hours. This study recommends building owners as well as designers to integrate electrical lightingdaylighting by intelligent lighting control, particularly timescheduling control, for further energy saving in buildings.

Field measurements in atrium spaces and linked corridors at the College of Applied Medical Sciences, Najran University, were conducted. Daylight availability and indoor illuminance were recorded and analysed. The horizontal illumination level indoors ranged from 300 lux to 3600 lux particularly during the midday due to the huge glazed roof and the clear sky condition of Najran City.

The amount of energy savings due to the lighting controls of time scheduling 6:00 am to 6:00 pm was calculated. The timescheduling control is effective in a climate of clear sky throughout the year. The daily electrical lighting energy saving for the atrium space and linked corridors at the first and second floors was $121.82 \mathrm{kWh} /$ day, whereas the annual lighting energy saving was $43856.6 \mathrm{kWh} /$ year. The total annual energy saving from all 25 colleges in Najran University is $1096380 \mathrm{kWh}$ /year. However, the total cost saving is about $(93,512.86)$ USD.

It is noted that there are still potentials to reduce energy consumption in the university buildings by retrofitting the lighting control system in other atria and courtyards throughout Najran university campus.

However, the study recommends the following:

Using an atrium in a hot arid climate should be considered to bring light to the centre of a large building. A daylight from a skylight atrium glazed roof should be controlled with shading devices to eliminate unwanted direct glares and prevent heat gain. An indoor illuminance of 100 lux can be, easily, provided by daylight for the atrium space and corridors at ground, first and second floors.

- The study found that the daylighting illumination level reached more than 5,000 lux and found an approximately 30 Klux in a certain time in the summer of June, so that the study suggests further research to assess the impact of roof shading systems such as motorised skylight blinds on controlling unwanted daylight glare in the atrium spaces.

\section{Acknowledgements}

The authors would like to acknowledge Najran University for supporting the publication of this research under grant number NU/ESCI/15/039 and NU/ESCI/16/050.

\section{References}

A. C. Menezes, A. C. (2014). Estimating the energy consumption and power demand of small power equipment in office buildings. Energy and Buildings, 75: 199-209.

Amin, A.T.M.N., Jarusombut, S., Thuy, T.T.B. \& Thanaprayochsak ,W. (2006). Environmental Management Measures For Influencing Human Behaviour Towards Sustainable Development. Regional Development Dialogue. 27(1): 85-100.

Abdou, O. A. (1997). Effects of Luminous Environment on Worker Productivity in Building Spaces. Journal of Architectural Engineering. 3(3): 124-132.

Alshaibani, K. (2001). Potentiality of Daylighting In A Maritime Desert Climate: The Eastern Coast of Saudi Arabia. Renewable Energy. 23(2): 325-331. doi: https://doi.org/10.1016/S0960-1481(00)00166-X

Aries, M., Aarts, M., \& van Hoof, J. (2015). Daylight and Health: A Review Of The Evidence And Consequences For The Built Environment. Lighting Research and Technology. 1-22. doi:DOI: $10.1177 / 1477153513509258$.

Atif, M. R., \& Galasiu, A. D. (2003). Energy Performance Of Daylight-Linked Automatic Lighting Control Systems In Large Atrium Spaces: Report On Two Field-Monitored Case Studies. Energy and Buildings. 35(5): 441-461. doi: https://doi.org/10.1016/S0378 7788(02)00142-1

Chow, S., Li, D., Lee, E., \& Lam, J. (2013). Analysis and Prediction Of Daylighting And Energy Performance In Atrium Spaces Using Daylight-Linked Lighting Controls. Applied Energy. 112: 1016-1024. doi: https://doi.org/10.1016/j.apenergy.2012.12.033

Costanzo, V., Evola, G., \& Marletta, L. (2017). A Review of Daylighting Strategies in Schools: State of the Art and Expected Future Trends. Buildings. 41(7): 1-21. doi:10.3390/buildings7020041.

Frank, S., Doug, L., Jeff, D., \& Josh, C. (2014). The Use And Environmental Impact Of Daylighting. Journal of Cleaner Production. 85: 462-471. doi: https://doi.org/10.1016/j.jclepro.2014.03.092.

Grondzik, W. T., \& Kwok, A. G. (2015). Mechanical and Electrical Equipment For Buildings. Hoboken, New Jersey: John Wiley \& Sons.

Halonen, L., Bhusal, P., \& Y, S. (2010). Guidebook on Energy Efficient Electric Lighting for Buildings. International Organizations: Aalto University, school of Science and Technology.

Hourani, M., \& Hammad, R. (2012). Impact of Daylight Quality On Architectural Space Dynamics, Case study: City Mall - Amman, Jordan. Renewable and Sustainable Energy Reviews. 3579- 3585.

Hua, Y., Oswald, A., \& Yang, X. (2011). Effectiveness of Daylighting Design And Occupant Visual Satisfaction in a LEED Gold laboratory building. Building and Environment. 46(1): 54-64. doi:https://doi.org/10.1016/j.buildenv.2010.06.016

IESNA. (2000). The IESNA Lighting Handbook. New York: Illuminating Engineering Society of North America.

Kim, G., \& Kim, J. T. (2010). Luminous Impact Of Balcony Floor At Atrium Spaces With Different Well Geometries. Building and Environment. 45(2): 304-310. 
Lechner, N. (2015). Heating, Cooling, Lighting: Sustainable Design Methods For Architects. Hoboken, New Jersey: John Wiley \& Sons.

Mahdavi, A., Rao, S. P., \& Inangda, N. (2013). Parametric Studies on Window-To-Wall RatioforDay lighting Optimisationin High-Rise Office Buildings inKuala Lumpur,Malaysia. Journal of Design and Built Environment.https:// ejournal.um.edu.my/index.php/jdbe/article/vie w/5332 Access on 12June 2019.

Mansour, T. A., Sawalha, S., \& Salem, N. (2013). A Mathematical Model for Solar Assisted Automobile A/C Based on Absorption Refrigeration System. International Journal of Mechanical Engineering (IJME). 2(4): 75-86.

Mardaljevic, J., \& Nabil, A. (2006). The Useful Daylight Illuminance Paradigm: A Replacement for Daylight Factors. Energy and Buildings. 38(7): 905-913

Mark, D., \& G. Z., B. (2014). Sun, Wind \& Light - Architectural Design Strategies (3 ed.). Hoboken, New Jersey: John Wiley \& Sons.

Obaid, R., \& Mufti, A. (2008). Present State, Challenges, and Future of Power Generation in Saudi Arabia. Energy 2030 Conference. 1 - 6. 10.1109/ENERGY.2008.4781073. 1-6. Atlanta, GA USA.

PE., K. (1991). Efficient Use Of Daylight In Commercial Buildings. Right Light Bright Light. Stockholm, Sweden.

Sabry, H. M. (2006). he Impact of Daylighting- Guiding Systems on Indoor Natural Light Penetration: Simulation Analysis for Light-Shelves
. Passive And Low Energy Architecture. 1-6. Geneva Switzerland. SEEC, S. E. (2018) Buildings. Retrieved from Saudi Energy Efficiency Center: https://www.seec.gov.sa/en/blog/buildings. 1220 Access on 10 August 2019.

Stanley K.H. Chow, D. H. (2013). Analysis and Prediction Of Daylighting And Energy Performance In Atrium Spaces Using DaylightLinked Lighting Controls. Applied Energy. 1016-1024.

USGBC, U. G. (2018). Daylighting Strategies. Retrieved from US Green Building Councel: https: / / www.usgbc.org/education/sessions/daylighting-strategies4775236. Access on 26 June 2018.

Veronica G., H. (2006). Improving Daylighting Systems for Deep-Plan Commercial Buildings. PhD. Schoole of Design, Queensland University of Technology, Queensland.

WWO, W. W. (2018). World Weather Online. Retrieved from https://www.worldweatheronline.com/. Access on 13 Jan 2019.

YILMAZ, F. SS. (2016). Proposal of a Façade Design Approach For Daylight Performance Determination In Buildings. A|Z ITU Journal of the Faculty of Architecture. 13(2): 57-64.

Zell, E., Gasim, S., Wilcox, S., Katamoura, S., \& Stoffel, T. (2015). Assessment of Solar Radiation Resources in Saudi Arabia. Solar Energy, 119, 422-438. https://doi.org/10.1016/j.solener.2015.06.031 